\title{
AGRARIAN REFORM AND THE SOCIETAL AND POLITICAL INTERESTS OF URBAN GROUPS IN LESS DEVELOPED COUNTRIES
}

By Rolf Hanisch

In most of the Less Developed Countries (LDCs), unequal structures of land tenure are the basis of the exploitative conditions under which the large mass of the rural population have to suffer. They are often the reason for the progressing marginalization of the rural lower classes and for the relative stagnation of agriculture.

Since World War II there has been a world-wide movement of agrarian reform which aims to break these structures. However, agrarian reforms have been implemented in a few countries only, i.e. reforms, which, as a basis for a modernization and mobilization of the rural areas, are disrupting the unequal conditions of land tenure, are expanding the supply of the necessary agricultural inputs, are democratizing their use and which would have thus created the condition for the broad mass of peasants to participate in the economic growth and progress.

This is the more astonishing since it is in relatively few countries only that full political power lies in the hands of (feudal) landlords. In many other countries, they have to share it with urban groups, the urban middle class and the urban bourgeoisie In other countries, they do not have any direct relevant influence on the political decision-making centres. The rural lower classes also succeeded sometimes in influencing the political parameter by collective actions, but could rarely acquire a lasting influence. However, if they did, they succeeded, in most cases, not on account of an autonomous and autocephalic organization, but only under the leadership and guidance of or in coalition with urban groups.

Hence, the key role of urban groups with regard to the modernization of agriculture and the question as to whether structural reforms (agrarian reforms) should be enforced or not becomes evident. This is a problem which, up to now, has been raised only marginally in scholarly discussions and which will be dealt with in greater detail in this paper.

\section{THE INDUSTRIAL AND NON-INDUSTRIAL TOWNS}

\subsection{The Thesis of Gramsci}

In his studies on the revolution in Italy in the 19th century, Antonio Gramsci enunciated a few interesting theses on the urban-rural relation in revolutionary upheavals ${ }^{1}$. These theses are of some importance for our problem: Gramsci makes a political difference between industrial and non-industrial cities: Industrial towns are, in general, "more progressive" than the rural areas which depend on

\footnotetext{
1 These were taken up by Charles Tilly: Town and Country in Revolution (in: Lewis, J. W. [ed.]:
} Peasant Rebellion and Communist Revolution in Asia, Stanford, Calif. 1974, pp. 271-302). 
them. Hence, any revolutionary movement in industrial towns will also involve the hinterland. The situation is different with regards to non-industrial towns which depend on the hinterland which they dominate, exploit and from which they live. These towns are vulnerable if an extensive mobilization of the rural area is directed against them. This would only be possible if the rural uprisings, which are, very often, restricted to scattered localities only, are coordinated and organized at a national level - only this would allow a transfer of power.

This seems to be possible only as a result of a coalition with urban allies. But the immanent contradiction between urban and rural area means that every claim put forward by the rural area has to meet with rejection in the urban area, since its fulfilment would do away with that very type of town. Therefore, in this system, Gramsci does not consider a rural-urban coalition of the lower classes to be very probable or acceptable. Tilly ${ }^{2}$, on the other hand, has rightly claimed that opposition groups in the centre could still be successful in looking for a rural basis to overthrow the whole system. However, revolutionary rural-urban coalitions in this social system would rarely outlast the revolution and the rural sector would be able to realize its expectations only in the unusual case that it knew how to organize itself on a long term and on a large scale basis.

This is different with regard to the industrial town which exists on account of its own production capacity. In the model, because of the constant introduction of technological innovations, a permanent and essentially autonomous growth, based on specific accumulation, which increases constantly and at long term the income of all citizens, is assumed. The urban-rural relationship is characterized by a mutual interaction process, by the exchange of agrarian products for industrial goods and by the activation of the rural area under the technological and economic guidance of the town. The tendency is for the contrasts between urban and rural areas to vanishing and for the rural areas to loose their importance for the overall economy. This explains that in "mature" industrial nations the urban sector subsidizes the rural one. This is possible (from an economic point of view) because of the marginal importance of the rural sector as well as of the high level or productivity and income in the urban sector. Politically, this support is thought advisable because of the comparably high mobilization capacity of farmers which is mainly determined by the rapid progress of the transformation process and by the expansion of communication, by the adjustment of the rural way of life to the urban one or, at least, by the orientation of the expectations of the rural population towards the urban ones.

\subsection{The Towns in LDC's}

The situation is completely different with regard to towns in LDCs. Here it is not essentially a question of productive industrial towns (even when industry is available) but of parasitical towns whose exploitative character assimilates them to the classical non-industrial town. In many LDC's the involvement in the world market stimulated the agricultural market production and increased land-concentration. Landlords migrated more and more to the town, the small ones to the

2 op. cit. p. 293. 
provincial capitals, the great ones to the national capitals or primate cities. A few went (at least for regular visits) even further (to the metropoles). The change of residence resulted from the desire for a change in the way of life and for an adjustment to the European life style. In addition, in the towns more attractive investment possibilities (real estate, trade, industry) and employment prospects (by acquiring academic education, etc.) are offered than in the rural area. Therefore, landlords and the most agile and mobile groups of the rural population moved to the cities so that one can speak not only of a "capital" but also of a "brain" drain.

The formation and development of new urban groups (in the administration, in trade and services, among the academic intelligentsia, capitalist entrepreneurs and modern wage-earning proletariat) was essentially determined in character, rapidity of formation and scope by the dependent involvement in the world market. As "bridgeheads", intermediaries between national and the international system, their position and development have been fragile and ambivalent. Economically, they depend on the productive capacity of their societies and the requirements of the world market. Their attitude is determined by their cultural-national and social composite role as class with high consumption needs. Hence, they draw their image and aspirations from societies with a considerably higher economic productivity and a higher degree of economic development than that characterizing their own societies.

Higher incomes through employment in sectors of the economy having a high productivity are restricted to a small group of the population, whose size, however, differs between societies. "The low productivity of the greater part of the economic structure compels, on the other hand, an economic organization based on exploitation and providing high incomes to the minorities" 3 . The control of state apparatus and political power has an essential role 4 . It is the prerequisite for the control and exploitation of goods and markets in economic activities with low productivity (e.g. the agricultural sector), by the (private) control (guaranteed by government) of land, credit etc., of government taxes, of the monopolistic control of intermediate trade, etc. The result is the contradictory attempt at encouraging a high market production on the one hand and, at skimming off a high surplus value at the other hand. Even by forcing the transfer of income from "insular" sectors with a high productivity - e.g. the mining industry - or by realizing income transfers from abroad ("development aid") groups which dominate bureaucracy and politics can acquire higher incomes 5 .

The limited potential in most countries (only the oil monarchies might be an exception) compels these privileged groups to remain exclusive. Also from a political point of view they find themselves in an ambivalent position. On the one hand, they have to try to exploit the producers and to retain their exclusive character and their dominance vis-à-vis the underprivileged local groups, on the

3 Sunkel. Osvaldo: Transnationale kapitalistische Integration und nationale Desintegration: Der Fall Lateinamerika (in: Senghaas, Dieter, Hrsg.: Imperialismus und strukturelle Gewalt. Frankfurt 1972, p. 289 [My translation]).

4 Cf. Alavi, Hamza: The State in Post-Colonial Societies - Pakistan and Bangladesh (New Left Review 74, July-Aug. 1972, pp. 59-81); Saul, John S.: The State in Post-Colonial Societies Tanzania (The Socialist Register 1974, London 1974, pp. 349-372); Meillassoux, G.: A Class Analysis of the Bureaucratic Process in Mali (The Journal of Development Studies, January 1970).

5 Sunkel, Osvaldo, 1972, op. cit., p. 285; about the connections between the rising industrial bourgeoisie and political elites in Korea cf.: Kyong-Dong Kim: Political Factors in the Formation of the Entrepreneurial Elite in South Korea (Asian Survey, Berkeley, May 1976, pp. 465-477). 
other hand they have to try to keep political costs (repression by the police, security forces etc.) at a low level and to limit the scope of their pacification programmes (reduction of the exploitation rate, distributive, welfare and social measures, etc.). Both strategies might become necessary in order to keep the power and the privileges in the case of the political mobilization of the underprivileged.

A better and "cheaper" way is the ideological manipulation of the political conviction of the masses. An attempt is made at achieving this by (promoting) nationalism against external threats, dependence and exploitation, but also by furthering primary relationships (by tribalism, regionalism, religion, etc.), by developing rituals and manipulating symbols ${ }^{6}$. Thereby, besides its manipulative character, nationalism often has real economic objectives as well which result from the antagonism between foreign and local exploiters. The colonial situation has caused the promotion of these groups, but it has also hindered their full development since they had to share the decisive functions of intermediaries and exploiters with foreigners - primarily Europeans. Thereby, they themselves succeeded mostly in occupying dependent and subordinate positions, either on account of the politically dominant position of the colonial agents who used the method of racial discrimination to defend their position, or on account of the dominant capacities of the foreigners (education, knowledge of management, capital).

Hence, the attainment of "national" (political) independence was a necessary precondition for these groups to push themselves into politically monopolistic positions. They were the ones, who in Africa and in many Asian countries have been the agents of the nationalist movements, whereby they often succeeded in mobilizing the lower classes. The result was that the indigenous elites succeeded more or less - in ousting the foreign bureaucrats, officials and enterprises, but this hardly brought about any change for the masses (particularly the rural ones). The government setup was considerably extended, especially in countries where high incomes can only be achieved through it. The urban middle classes thus knew how to increase their individual incomes (their wages and salaries in the case of direct employment) and the collective incomes (by the expansion of infrastructure and, sometimes, by measures of social welfare). Hence, in most of those countries, personnel expenses take up a disproportionately high amount of the total national expenditure and the development policy of the government is concentrated, with priority, on the expansion of the (urban) infrastructure and on the promotion of industrialization.

Besides transfer from abroad, which are very important in some countries, government expenditure is often financed by a tax system which assesses disproportionately the lower income groups integrated into the economic process ${ }^{7}$. In some African and Asian countries, this applies particularly to the cash-crop producing peasant agriculture ${ }^{8}$.

\footnotetext{
6 On the use of political rituals in the Philippines cf.: Suhrke, A.: Political Rituals in Developing Nations: The Case of the Philippines (Journal of Southeast Asian Studies (Singapore), March 1971,

7 Cf. Elliott, Charles: Patterns of Poverty in the Third World. A Study of Social and Economic

8 Cf. op. cit., p. $350 \mathrm{ff}$.; Bird, Richard M.: Taxing Agricultural Land in Developing Countries (Cambridge, Mass., 1974, p. 42 ff.).
} 


\section{DEVELOPMENT POLICY UNDER URBAN BIAS}

There is hardly a LDC which has not made an effort to promote industrialization. While the scholares still debated academically whether industrial development should be given priority over agricultural or vice versa and the majority was in favour of the first alternative 9 , there was no doubt for the urban middle classes that they would give first priority to industrialization.

However, the specific industrialization pursued in most of the LDC's does usually not correspond to the demands of a development policy which would benefit the overall system (creation of job opportunities and of mass income, increased integration of local business cycles, positive spill-over effects towards the rural sector). Instead it corresponds to the interests of the groups which promote it politically (the urban middle clases) and to the interests of those which allowed its realization economically (the multinational companies in the first place). The positive effects for the overall system and for agriculture were rather limited, whereas important negative consequences can be ascertained for the rural sector. Hence, it is justifiable to speak of a "perverse" rather than a "generative" industrialization.

In most peripheral societies, industrialization was made possible and enforced against the metropolitan interests by means of various measures of foreign trade policy (tariff protection, import quotas, manipulation of exchange rates). These forced the multinational corporations to invest in the manufacturing sector (to which they would hardly have been prepared) and which also made it more attractive for indigenous capital to invest in that sector. The type of industrialization concerned is that of the so-called "import substitution" with a strong bias towards the "production of luxury consumer goods". The various tariff and protection measures and subsidies did not turn out, in general, to be short-term measures. They were institutionalized since the monopolistic or oligopolitical production structure does not pass on, by price reductions, technological improvements etc., to the consumers. By paying the high prices, the consumers have to finance industrialization more or less permanently. This applies particularly to agriculture whose terms-of-trade deteriorated, in comparison to those of industrial goods. Rural producers and consumers are thus most negatively affected and have to bear the main costs.

The manipulation of exchange rates in many countries, with the permanent tendency to overevaluate them, also has negative consequences for the rural sector. Its objective is to reduce the price of imported goods, of the consumer goods of urban groups. Thereby this measure is appropriate to bring down the price level of the goods produced internally. Since the agricultural (and mining) primary commondities exported, are fixed in Pound Sterling and US Dollar at the exchanges in the metropoles, the overevaluation of the local currency implies, that these products are not hampered in their export markets (as industrial export goods otherwise would be), but are getting a less than normal equivalent for their export products in local currency. But the artificial price reduction of invest-

$9 \mathrm{Cf}$. as one of the latest examples: Flanders, M. June: Agriculture versus Industry in Development Policy: The Planner's Dilemma Re-examined (The Journal of Development Studies London, Vol. 5, No. 3, April 1969, pp. 171-189). 
ment and capital goods emphasizes another tendency which characterizes anyway almost all fields of the so-called "modern" sector and particularly the industrial and mining production: the bias towards capitalintensive investments.

The dependence theoreticians have pointed out that there is actually no tendency to do away with the precapitalistic sectors as a result of periphery capitalism (as the classical economistic theory pretends to know) but that these are rather growing in the sense that more and more people have to find employment in these sectors. The competition of the modern enterprises (which establish themselves in all sectors of the economy, i.e. in agriculture, in the processing industry and in the services) and the inadequate equipment with resources (land, capital) in relation with the increasing number of workers leads to a reduction of productivity in these sectors and to a fixation at a lower level of the economic activity.

The urban bias of the policy, the main feature of which is the expansion of infrastructure (primarily the urban one), of the government apparatus and of the public sector, and of the promotion of industrialization (agriculture and the rural sector being usually neglected), can be ascertained in almost all countries in which the feudal aristocracy no longer retains evident power. Keith Griffin ${ }^{10}$ mentions that investments in agriculture are more important than their share in the national product only in Venezuela and in Israel. In most of the other countries, they are considerably lower. Thus, a FAO-study on 18 LDC's for the period 1960-65 showed that only (an aggregate of) $12 \%$ of all investments were effected in agriculture. Their share in the national product was $30 \% 0^{11}$. While the momentary share in the gross national product cannot be a significant criterion for the portionment of investments, the imbalance still appears to be excessive. It is obvious that agrarian programmes are not granted great priority in allocation of personnel and financial means. Local circumstances of structural nature or resulting from the political "bargaining process" can bring about more or less considerable modifications. Thus, in Malaysia the geographical location of the Chinese and Malays, the first in the urban, the second ones in the rural sector is undoubtedly also one of the factors which are responsible for the relatively great efforts made by the government (dominated by the Malays) in developing the rural areas ${ }^{12}$. As regards Pakistan, Burki has described the change in the political determination of the economic policy ${ }^{13}$. The ideological preferences of the political groups which determine the rural policy in India have been analysed by Nicholson ${ }^{14}$.

The "development policy" centred in the urban area became possible, because of the fact that the great landlords have not opposed it decisively, although the classical controversy of free trade against tariff protection (i.e. export agriculture $\mathrm{v} / \mathrm{s}$ industrialization) was fought out politically in many LDC's. The solution of

10 Griffin, Keith: The Political Economy of Agrarian Change. An Essay on the Green Revolution (London 1974, p. 179)

11 Sczczepanik, E. F.: Agricultural Capital Formation in Selected Developing Countries, Agricultural Planning Studies No. 11, FAO 1970, quoted by Griffin, Keith, 1974, op. cit.

12 Ness, Gayl D.: Bureaucracy and Rural Development in Malaysia (Berkeley, Los Angeles 1967, p. 98 ff., p. 121).

3 Burki, Shahid Javed: Politics of Economic Decisionmaking During the Bhutto Period. (Asian Survey, California, Vol. XIV, No. 12, Dec. 1974).

14 Nicholson, Norman K.: Panchayat Raj, Rural Development and the Political Economy of Village India (South Asia Occasional Papers and Theses No. 2, Cornell University, 1973); Rural Development Policy in India: Elite Differentiation and the Decision Making Process (Center for Governmental Studies, Northern Illinois University, 1974). 
this conflict in favour of industrialization was facilitated on account of the fact that the landlords understood how to diversify their business interests (as well as their residence) in the urban sector. Hence, they have to be interested in its expansion too. Thus, the social conflict between urban bourgeoisie and rural (feudal) aristocracy became less acute. The instrumentalization of landreforms by the urban bourgeoisie to harass and subdue the landed elite was not necessary, since the urban dominance could also be secured anyway.

The (urban) bourgeoisie, naturally, is not only interested in creating the political preconditions for industrialization, but it had, moreover to show interest for the creation of the economic conditions. This comprised the transformation of the stagnating "traditional" agriculture into a modern one with an efficient production which, on the one hand, provides sufficient cheap foodstuff to the urban consumers and raw materials to industry, and which, on the other hand, allows, as growing market the expansion of industry. However, this interest, which can only be satisfied at long term, collides, in the political practice, with the temptation - which can be realized at short term - of securing, as far as possible, a large share of the national budget. On account of the general scarcity of funds and of the relative instability of these social groups, expensive programmes of rural development always call for a restriction of the urban needs (which, because of their nature and extent cannot be compared with the rural ones). Even funds which have not been raised in the country, like development aid funds, make no exception in that respect. Thus, in 1954, the Philippine Congress forced the displacement of the American development aid from agriculture, on which, until then, as it ascertained in a joint resolution of both Houses, the "emphasis had unjustly lain", to the benefit of the industrial development ${ }^{15}$. When enforcing the selfish interests of the group, it is readily argued, in nationalist and even anti-imperialist terms that the aim is to draw up with the lead of the metropoles, that these metropoles tried to prevent this, etc. Significant of this style is a "anti-imperialist" memorandum which a representative of the national bourgeoisie of the Philippines had prepared for the Constituent Assembly in 1971 and which was even published by the marxist Monthly Review Press ${ }^{16}$.

\section{The Emphasis on Agricultural Growth}

\subsection{The turn of the tide}

In almost all countries, the neglect of the rural sector has reached the point when the governments (dominated by the urban groups) were forced to grant greater attention to rural development, namely when the poverty of the rural area begins to spread to the urban area. "Eventually, however, the system will begin to collapse. This will occur when the subsidy required for the support and

\footnotetext{
15 Golay, Frank H.: The Philippines: Public Policy and National Economic Development (Ithaca 1961, pp. 299-301). In 1951-54 US-aid to agriculture accounted for $35 \%$ of all american development aid to the Philippines. Afterwards $(1955-57)$, its share decreased to $11 \%$, whereas the share which went into industry and mining increased from $4 \%$ to $32 \%$. US-aid financed as much as $29 \%$ of all public investments in the Philippines in those days.

16 Lichauco, Alejandro: The Lichauco Paper - Imperialism in the Philippines (Monthly Review, New York, Vol. 24, No. 3, July-August 1973).
} 
expansion of the industrial sector is greater than the resources which can be squeezed out of agriculture. When that point is reached, policy will have to be switched to favour agriculture, regardless of the regime in power" ${ }^{17}$. The displacement of the rural problem and of rural poverty is effected physically by migration from the rural area and by the growth of the marginalized masses in the urban slums. The standard of living of the urban middle and upper classes is also affected, for example on account of the stress laid on the urban infrastructure and growing criminality which forces the rich people to make higher contributions towards their security (in a few countries, even by having fortified and protected residential settlements constructed within the towns or in the suburbs).

The shortage in the supply of foodstuffs and of primary commodities as well as the increase of their prices affects the urban groups in an even harder way. The workers who depend on their salary and whose real income is determined by the price of foodstuff as well as the entrepreneurs who, when negotiating wages, have to take (foodstuff) prices into consideration, are equally effected. Insufficient internal supply can be adjusted by imports over a certain period. But growing difficulties in the balance of payment of most of the LDC's finally force these to restrictions, since even the American supplies of PL 480 have had, increasingly to be paid in hard cash in the last years.

\subsection{The case against landreform}

A reorganization of rural land tenure as prerequisite for its modernization and development has regularly been demanded by urban groups, and measures of agrarian reform are sometimes initiated. However, the agrarian policy still focuses mostly on the technocratic measures promoting production directly. There are numerous reasons for this.

The relation between an increased agricultural production and more equitable conditions of land tenure seems to be plausible if one considers the utilization, then becoming possible, of land reserves not used previously and controlled by great landowners in Latin-America, and motivational incentives to tenants in Asia. On the other hand, it is almost unanimously agreed that measures of land transfer increase production only if government is prepared to extend "supporting services" (credit, input supply, extension, marketing). Otherwise, it would run the risk of a decrease in the market production on account of higher subsistance consumption of the land reform peasants and on account of the collapse of the (exploitative) service structure (controlled by landlords and moneylenders) which was available previously. Hence, agrarian reforms, land transfers plus the organization of services, are quite expensive.

Therefore, bourgeois governments are put into a dilemma: their fear of hard political disputes with the landlords and their ideology of "property" do not allow them to transfer land without compensation, nor to confer to the transfer more than a purely marginal confiscatory character. If the government takes charge of most of the costs, the reform is so expensive that only a very slow

17 Griffin, Keith: Policy Options for Rural Development (Oxford Bulletin of Economics and Statistics, 1973,35 [4], p. 262). 
reform process can be expected. On the other hand, it can transfer shares and industrial bonds or the like to the landlords and allow the peasants to pay the purchase price of their land in annual instalments. In this case, the position of the peasants will change marginally only for a specific period. At any rate, a rapid realization of the reform is not to be expected and could hardly attain economically (as well as politically) the objectives for which it was intended.

Hence, many a bourgeois government may have started a reform with the best intentions - and not the least for political reasons. However, afterwards, they had to reduce its pace considerably. Robert Kaufman ${ }^{18}$ has made an excellent description of these obligations for the Frei government in Chile: On account of the dependence on the multinational corporations and on the world market, it did not succeed in drawing from the copper production and copper export the funds to be utilized for the programme of agrarian reform as it intended to do. The competitive claims of the urban groups - from the entrepreneurs to the syndicates and practically all non-leftwing parties - became perceptibe as, in 1968, when the general economic situation called for indispensable cuts in the budget and the verbal recognition of the necessity of the agrarian reform, to which everyone was prepared, was no longer sufficient. During the crisis, it turned out that the peasant unions could hardly gain a hearing in comparison to other interests, and the cuts in the budget for the programme of agrarian reform were, therefore, twice as high as those of the other items of the budget. The resolute opposition of the (left-wing) technocrates of the agrarian reform departments and, finally, the financial support of the USA, first allowed the partial countermanding of the cuts and the further realization of the reform. The ambivalent position of the "progressive" urban groups towards the agrarian reform is described by Kauf$\operatorname{man}^{19}$ : "The role was obviously more positive at those levels and stages where the costs of the program were least apparent. Early in the land reform and within the Congress, urban dissatisfaction undoubtedly contributed to the landowner's sense of isolation and encouraged the urban upper class to remain on the sidelines. As the reform moved to the administrative level and as urban sacrifices became necessary, however, the behaviour of the different city sectors became negative. Though many of these groups did not explicitly abandon the rhetoric of reform, it became increasingly difficult to channel their behaviour in directions that did not seriously detract from meaningful change".

In Columbia as well, the precarious situation of the budget and the balance of payment, on account of the falling prices for coffee, led to a considerable curtailment (from 100 Mill. Pesos originally, to 20 Mill. Pesos) of the programme of agrarian reform which, anyway, was not to be taken seriously ${ }^{20}$.

\subsection{The technocratic approach}

Technocratic supporting measures for agriculture without change of land-tenure concentrate, purposefully or in their actual implementation on the owners of large estates and great landlords, turned out to be less expensive, simpler to implement

\footnotetext{
18 Kaufman, Robert R.: The Politics of Land Reform in Chile, 1950-1970. Public Policy, Political Institutions, and Social Change (Cambridge, Mass. 1972).

19 op. cit., p. 228.

20 Duff, Ernest A.: Agrarian Reform in Colombia (New York, Washington, London 1969, p. 167).
} 
administratively and easier to enforce politically. Thus, the supply and the subsidization of measures like credit, extension, fertilizers, machinery etc. with scarce funds promise a greater success if only the so-called "progressive" owners of large estates are appealed to. Real programmes for small farmers usually require an extended administrative setup. Their success is less certain since it is easier for urban agricultural officers to understand the value and motivation structure of capitalist farmers than of peasants living almost on subsistence.

In general, agricultural development programmes are affected by this "urban bias", the lack of effective participation of the rural lower strata in the planning and implementation process, the incapacity of the urban officers to feel any empathy with the peasants, their unwillingness or inability to assert themselves against established rural interests. Michael Lipton ${ }^{21}$ has pointed out that agricultural planning under "the urban bias" can only be successful under three conditions: feasibility with the help of large organizations centrally directed, absence of conflicts with the rural elites or the rural values and attitudes. In India (to which Lipton refers, but also in other countries), it has initiated a remarkable rural progress: "Thus Indian planning can eradicate malaria, build big dams, provide big areas with electricity. But if there is intrarural power struggle, as with land reform, or a complex situation requiring detailed case studies, as with diffusion of innovation ... then planning under urban bias is unlikely to succeed". Lipton ${ }^{22}$ describes as follows the frustrations of the planners to whom he imputes the best intentions: "The townsman is contractualist and thus disguises his failures from himself by paper legislation ... The townsman's life is compartmentalized, and he can learn to improve some aspects of it without much effect on others; so he honestly believes in show piece planning through model farms and isolated research stations".

Typical for the policy followed hitherto was, therefore, the concentration on a few high-cost large-scale projects (from dams and irrigation plants to fully mechanized model farms) on the one hand, and, for programmes of social and economic development, the "carpet approach" on the other hand, i.e. government services were supplied to whole villages and districts. The latter implies that the actual beneficiary has always been the rural elites, owners of large estates and middle farmers. Since the middle of the sixties, there has been a growing tendency to rely purposely on the privileged "progressive" farmers. The aid measures and the successes (in production) in the framework of the so-called "Green Revolution" demonstrate this tendency. Several agrarian reforms also designate the "progressive" family farmer as their model. In legislation concerning land reform, the owners of large estates which are managed in a modern way (i.e. with the use of machinery), plantations and agricultural large-scale farms are often explicitly excluded from land distribution.

The decrease in the price of agricultural inputs, the raise of prices (sometimes by government decree) for specific agricultural products, the supply of institutional credits, the establishment of co-operatives and marketing organizations has benefited primarily the farmers with larger estates - and the corrupt officers and functionaries who administer these institutions. Thereby, they are now at a double advantage since the rural taxes after World War II, or rather at the end of

21 Lipton, M.: Urban Bias and Rural Planning in India (in: Bernstein, H. [ed.]: Underdevelopment \& Development. The Third World Today. Harmondsworth, Middlesex Engl., 1973, p. 239).

22 op. cit., p. 240. 
the colonial era, lost much of their importance and were sometimes even abolished ${ }^{23}$. Prosperous owners of large estates and agricultural entrepreneurs are, therefore, subsidized by the community and have hardly any taxes to pay. Griffin ${ }^{24}$ rightly points out that the exemption from taxation is neither justified in the terms of the argument on "growth" nor in that on "equality", since, for the mass of peasants, it only represents a marginal benefit.

\subsection{In search of new target groups}

In a few countries - namely in connection with the introduction of high yielding varieties (HYV) - a spectacular success has been achieved as regards rice, corn and wheat by pursuing this technocratic policy of agricultural development. However, since the number of agricultural farms covered by these programmes was limited and on account of the reaction of the new varieties to virus disease and to weather conditions, the expected long-term breakthrough in production could not be achieved.

Hence, in many LDC's, the focus of agricultural policy is shifting to include two very different groups (sometimes concurrently) as agents of change in the countryside and targets of public development efforts and aid:

On the one hand, there is an attempt at continuing even more consequently the agrarian policy orientated only on the sectoral production increase, at inducing even the townspeople to become active in the agricultural production, as for example by the "Operation Feed Yourself" which has started in Ghana (since 1972) or by agroindustrial combinates in Iran, at forcing large-scale industries and multinational corporations to produce a certain amount of foodstuff in relation to their labour force (Philippines since 1974) or at inducing these to such activities by granting favourable depreciation allowances, tax reductions and the like (Brazil) ${ }^{25}$. This agrarian policy is likely to intensify the social inequality in the rural areas, and between urban and rural regions and to accelerate the marginalization of the masses. If the peasants lose their economic function of supplying the townspeople with agricultural products (in exchange for services and industrial goods), the urban interest in their development will be even more restricted. On the other hand, up to now, one can hardly speak of an improvement of the food situation in general. The solution to the problem of famine in the world has not only a technical aspect (how can more foodstuff be produced) but is determined, to a larger extent, by an economic aspect (how the starving people can buy foodstuffs). The problem of purchasing power seems to be dominant and primary. Therefore, a high-cost production of foodstuffs which expels the peasants from the rural areas, without opening up alternative prospects of employment cannot solve the problem of famine, particularly because this policy is evidently adjusted to the food habits of the urban middle class, i.e. to the production of meat and of animal products. These "luxury foodstuffs" are out of reach for the starving masses. The basis of production of the foodstuffs which are accessible to the sub-groups is eventually even more restricted.

23 Bird, Richard, M.: Taxing Agricultural Land in Developing Countries (Cambridge, Mass. 1974,

24 Gr. 34/35). Keith: Policy Options for Rural Development (Oxford Bulletin of Economics and Statistics, $1973,35[4]$, p. 263).

25 Hanisch, Rolf: Growth or Equity? Reflections on Some Recent Tendencies in the Agricultural Policy of LDC's. (Intereconomics, Hamburg, No. 5, 1976, pp. 146-149). 
The alternative would be to place rural development on a broad basis and to let the rural masses participate in it. Besides other measures of an integrated rural development, land reforms and government programmes of development which appeal directly and exclusively to the small farmers are to be considered. In India, in the Philippines and in some other countries, such programmes have been set up since a few years ${ }^{26}$.

The World Bank is increasingly aiding small farmer programmes as well ${ }^{27}$. But, even these small-farmer programmes are not yet focusing on the lowest strata of the rural population: marginal peasants and landless labourers are still - in practice - excluded. But this approach tries to expand the coverage of the hitherto existing agricultural programmes to include additional groups into the developmental process, not just for philantropic reasons ${ }^{28}$. In quite a few countries small farmer programmes seem to serve legitimizing government activities, which are not conductive to improve the life and prospects of the rural masses ${ }^{29}$.

Up to now, we have shown that one cannot proceed from a common social basis between the relevant urban groups and the rural subgroups with the aim of eliminating the exploitative structures which affect the peasants. A union, a mutual understanding or even a personnel symbiosis between the dominant rural and urban groups seem rather to prevent this liberation. This explains the lack of success or rather the poor effectiveness of the movement of agrarian reform in most of the LDC's.

\section{AGRARIAN REFORM AS AN INSTRUMENT IN THE POLITICAL BAR- GAINING PROCESS}

\section{1. "Idealism" as a source of agrarian reform?}

This is conclusive even though the conception of agrarian reforms has been conferred a symbolical character, and, as such, has hardly open oponents, particularly in government circles, since it is attributed a legitimizing function for the social and national character of every government authority. Very few governments think that they can afford to renounce to this, even verbally. This is why there has been a series of reforms, some of which could achieve a few important results. In that respect, protagonists of the agrarian reform and, in

26 Cf. on the Small Farmers' Development Agency and the Agency for Marginal Farmers and Agricultural Labour in India: Jodha, N. S.: Special Programmes for the Rural Poor: the Constraining Framework (Economic and Political Weekly, Vol. 8, March 31, 1973) and the article by Theodor Bergmann in this journal; on the Massangana-programme in the Philippines: Iglesias, Gabriel U.: The National Rice-Sufficiency Program of the Philippines: A Case Study in the Implementation of a Development Program. Focus on Massangana 99. (Quezon City 1975); on "supervised credit programmes" in various latin american countries: Nisbet, Charles T.: Supervised Credit Programs for Small Farmers in Chile (InterAmerican Economic Affairs, Vol. XXI, No. 2, Autumn 1967); Miller, Fred: Supervised Credit and Agricultural Development: A Peruvian Example (Inter-American Economic Affairs, Washington), Vol. XXIII, No. 4, Spring 1970); Adams, Dale W. et al.: Is Inexpensive Credit a Bargain for Small Farmers? The Recent Brazilian Experience (Inter-American Economic Affairs, Vol. XXVI, No. 1, Summer 1972).

27 Weltbank: Annual Report 1975 (o. O., o. J.): McNamara, Robert S.: Address to the Board of Governors (Washington D. C., September 1972, p. $8 \mathrm{ff}$.); Address to the Board of Governors (Washington D. C., September 1974 , p. 2 ff.).

28 Tetzlaff, Rainer: Multinationale Entwicklungspolitik und die Entwicklungspolitik der internationalen Organisationen am Beispiel der Weltbank (in: Tibi, B./Brandes, V., Hrsg.: Handbuch 2: Unterentwicklung, Frankfurt/M. 1975); Investment in the Poor. Zu einer neuen Entwicklungsstrategie der Weltbank in der Landwirtschaft (Zeitschrift der Osterreichischen Forschungsstiftung für Entwicklungshilfe 1975/III); Feder, Ernest: The new World Bank Programme for the Self-liquidation of the Third World Peasantry (in: The Journal of Peasant Studies, Vol. 3, No. 3, April 1976 
different ways, some scholars too, always point out the "idealism" of the single politicians or impute that they are "comparatively enlightened and aware of the social and economic problems of the country" (as Duff worte about A. Lleras Camargo in Columbia). This may be the case occasionaly not only as regards politicians but particularly in the case of the numerous technocrats in the bureaucracies involved in the agrarian reform. These are not always corrupt throughout and/or landlords' agents, as has been repeatedly imputed, but perform their reformative work sometimes with real dedication and try to carry out efficiently the task assigned to them. Ideological involvement can give impulses and overcome bottlenecks occasionally. However, at long term, it is rarely a supporting power which can force the solution of such a decisive problem as is the change of the conditions of land tenure. The failure encountered by Vinoba Bhave and his movements is surely one of numerous examples for this ${ }^{30}$.

Thus, successful agrarian reforms can only originate in the political process, the disputes over power between the social classes, parties, unions, factions or even individuals.

Political actors can push on the question of agrarian reform as an objective in itself. But they can also confer to it an instrumental character, solely to achieve or secure political power. In the second case, it can be expected that the agrarian reform will have served its function and will be abandoned if the objective of achieving and/or securing political power is attained, solely by propagating the objective of an agrarian reform (under certain cirsumstances without realizing it), if other means appear to be more appropriate or if it turns out that the agrarian reform jeopardizes political stability and power instead of guaranteeing and stabilizing them.

We can differentiate between three situations in which urban groups try to extend their power in the political process by broadening their legitimation basis in using the question of agrarian reform as an instrument.

\subsection{The quest for legitimacy: the opposition seeking power}

Opposition groups which want to gain power can try to mobilize the peasants, to organize them and/or try to win them to their cause, e.g. of a bourgeois opposition whose social basis are the urban middle classes and which tries to enforce "modernization" in the framework of a liberal-democratic and private capitalistic order against traditional feudal and military oligarchies. It can strive to broaden its basis by organizing the peasants or try to mobilize these for themselves in elections (where these are possible) by promoting the question of agrarian reform. Once in power, however, it is generally subordinated to the obligations which we already described in detail. Their readiness to cooperate with the traditional elites is greater than their readiness to enter into a conflict as long as their own interests are not concerned. Their effort towards the "legality" of the reform process, the

29 Cf.: Stone, Carl: Political Aspects of Postwar Agricultural Policies in Jamaica, 1945-70 (in: Social and Economic Studies, Vol. 23, No. 2, June 1974).

$30 \mathrm{Cf}$. Oomen, T. K.: Non-violent Approach to Land Reforms: The Case of an Agrarian Movement in India (Zeitschrift für Ausländische Landwirtschaft, Vol. 9, No. 1, March 1970); Bergmann, Theodor: The Bhoodan and Gramdan Movement in India: A critical Assessment of Achievements and Failures (Internationales Asienforum, München, Vol. 5, No. 3, 1974). 
high costs and the necessity to adjust these to the competitive urban claims, and, finally, the very time-consuming development of the reform results therefrom. This does not apply only in the case of Bolivia and of Mexico, for which Lyman/ French makes the following statement: “... enthusiasm and militancy towards reform in favor of rural masses declines as the new political leadership consolidated its authority and altered its power base". On account of the very limited results of the liberal-democratic reform approach, one can, therefore, speak of its failure ${ }^{31}$.

The agrarian reforms of the Accion Democratica (AD) in Venezuela is an instructive example illustrating how a radical party did not keep to these obligations, failed and, on its come-back, had drawn a lesson from this and proceeded hesitatingly as described ${ }^{32}$ : Since 1936, Romulu Betancourt and his followers, radical intellectuals belonging to the petty bourgeoisie, students, etc., had organzed peasants and workers against the oligarchic system. In 1945, with the masses as their base, they had gained power by a military putsch. The radical reforms which they them implemented, in accordance with their spontaneous base in the rural sector, in industry and in education, intensified their opposition to all established interests and finally provoked a reactionary counterputsch which revoked the reforms and rushed the leaders of the $\mathrm{AD}$ into prison or into exile. In 1958, as the $\mathrm{AD}$, after a further military putsch and after winning the elections, again acceded to power, new priorities had emerged: it sought the cooperation of and consultation with the established elites and the other (elitist) parties to stabilize its power. The result was a slowing down in the implementation of the programme of agrarian reform after the first demand, which had expressed itself spontaneously, had been satisfied and after the process of agrarian reform with the extensive elimination of the spontaneous participation of the peasant unions had been centralized. However, from 1958 to 1966, about 100.000 peasants are said to have obtained land ${ }^{33}$, undoubtedly more than in many other countries.

Socialist or communist opposition which acceded to power by the mobilization of peasants are, by comparison, more radical: the enforcement of the social revolution intended by them does not allow any long-term arrangement with the established interests. However, communists are also prepared to enter into coalitions and to conclude compromises whenever the situation calls for this. This applies particularly whereever they are not excluded from the legal political process and are prepared to contest elections. Thereby, in a few countries, they also succeeded in gaining power by exploiting the cleavage of the bourgeois parties. Up to now, this has been the case in the Indian federal states of Kerala (1957-1959, 1967-1969) and West Bengal (1967-1969), in Ceylon/Sri Langa (1969-1976), Chile (1970-1972) and Portugal (1974-1975). However, Their political power did not suffice for a revolutionary social change so that they had to have recourse to tactics. This is why, in almost all these cases they ran the risk of losing their base either because a radical (non-governmental) wing dissociated itself and tried to organize the peasants, or because the peasants tried, on their own and spontaneously, to occupy the land of the great landlords. The inherent

31 Lyman, P. N./French, J. T.: Political Results of Land Reform (AID Spring Review of Land Reform, June 1970, Washington, D.C., Second Edition, Vol. XI, p. 25).

32 Powell, John Duncan: Political Mobilization of the Venezuelan Peasant (Cambridge, Mass., 1971).

33 Op. cit., p. 163. 
tension between these coalitions, which was still itensified by the spontaneity of the radical base led, finally, to their disruption and to the expulsion of the communists from government power (often by non-legal methods).

Whereever the communists try to organize the peasants in an armed conflict, they proceed immediately, in the regions controlled by them, to the expropriation of landlords or, in regions where their influence is limited, insist, at least, on a reduction of rents and of the interests on credit. This serves as an instrument in the mobilization of rural masses and for the destruction of the local power of the exploiting class. But even in this case, they have to make tactical compromises, particularly when they judge the defence against external threat to be temporarily of greater importance than the solution of the internal problem of classes. In China ${ }^{34}$, for example, the uncompromising expropriation of the landlords (in the liberated Soviet regions), has been effected first since 1927, after the maoist trend had made ready headway. Previously from 1921-1927, the communist party had tried, with reformist rural platform to maintain a coalition with the left-wing elements of the Kuomintang. In 1937, this policy was again taken up to make possible a "national united front" against the Japanese. Besides the confiscation of the land property of the Japanese and of collaborators, the Chinese Communist Party restricted itself to obtaining a reduction of the rents and of the payment of interests. This policy was pursued for more than a year after the end of the Japanese war (until December 1946). Then the distribution of the "surplus land" of the landlords was enforced. After a short radical interval (Oct. 1947spring 1948), in June 1950, after the decisive victory over the Kuomintang, the agrarian reform law was passed. It initiated the most extensive land transfer in history, completed in 1953.

\subsection{The quest for legitimacy: The opposition in power}

A second scenario sees an opposition or a military group ascending to power without having recourse to the support of the rural masses and without formulating a reform programme. This is often the case with military coups which, if they have not only personal reasons, have a rather vague programme for "modernization" and a consolidation of military power.

Two reasons can cause these groups to effect a land reform after they have assumed power: the effective establishment of their authority can be seriously threatened by the subsisting power of the landlords.

Therefore, if they want to secure their authority, they have to break the power of the landlords by a land reform.

The expectations of the rural sub-groups can have risen so much as a result of the change of power, the power vacuum can promote their spontaneity to such a degree, that the basis threatens to make itself independent of any government authority and begins to effect a land reform autonomously.

34 Kuo-Chun, Chao: Agrarian Policy of the Chinese Communist Party 1921-1959 (Bombay, Calcutta 1960). 
According to $\mathrm{Tibi}^{35}$ and Abdel Malek ${ }^{36}$, the last applies to the reform in Egypt (1952). The two authors characterize the reform as a preventive measure conceived and implemented by the upper level to block the revolutionary efforts of the peasants. The spontaneity of the peasants might have been greater in Bolivia where the radical-bourgeois, urban MNR had risen to power in 1952, had made various statements in favour of agrarian reforms ${ }^{37}$, but did not feel any commitment nor obligation with regard to this problem. Its primary objective was the nationalization of the tin mines. However, left-wing cadres of the MNR party and of other (socialist) parties (like the Trozkysts) had begun to organize the peasants who then proceeded to spontaneous land occupation. Patch ${ }^{38}$ described the sequence of events as follows: "But in the late months of 1952 the situation in the rural areas was becoming unmanageable... There was always the possibility of a civil war between the campesinos and the "whites" or towndwellers. A comprehensive program of agrarian reform became absolutely essential both to put some order into the land redistribution, which the campesinos were carrying out themselves, and to make a convincing gesture that the party was indeed the exponent of the campesinos in had declared".

The land reform in $\mathrm{Iraq}^{39}$ after the abolition of the feudal moarchy by a group of officers led by A. Karin Kassem in 1958, can be traced back, primarily, to the objective of the putschists of making their "revolution" irrevocable by breaking the power of the landlords, without the peasants themselves exerting pressure. Already within the three months following the change of power, a law had been passed, on the strength of which expropriation was carried out. But then, on account of "legal, administrative and technical problems", most of the confiscated land was not distributed to the peasants (up to 1963 only $15 \%$ of the 11,2 Mill. donum $)^{40}$. Therefore, as in Egypt, the reform only brought about a shift of the peasants' dependence. As in Bolivia, the organization of "supporting services" was largely renounced so that the reform turned out to be an economic failure. Moreover, in Iraq, the military revolution first opened the way to a policy of industrialization whereas the emphasis of the feudal regime had lain on the agrarian sector.

According to Burki and Joshi ${ }^{41}$, the land reform of 1959 in Pakistan also showed the effort of the army, which had gained power in 1958 by a coup d'état, to create a political base, primarily among the peasants with medium farms (as well as among manufacturers with medium and small industrial companies) against the traditional elites. The political intention behind these efforts became evident as the Ayub-regime did not shrink from changing anew its coalition partners: "The new

35 Tibi, Bassam: Militär und Sozialismus in der Dritten Welt. Allgemeine Theorien und Regionalstudien über arabische Länder (Frankfurt/M. 1973, p. 235 ff.).

36 Abdel-Malek, Anouar: Agypten: Militärgesellschaft. Das Armeeregime, die Linke und der soziale Wandel unter Nasser (Frankfurt/M. 1971, p. $120 \mathrm{ff}$.).

37 Heath, Dwigth B./Carballo, Manuel: Bolivia's Law of Agrarian Reform (in: Heath, D. B./Erasmus, Ch. J./Buechler, H. C. [eds.]: Land Reform and Social Revolution in Bolivia. New York 1969, p. 40).

38 Patch, Richard Wilbur: Social Implications of the Bolivian Agrarian Reform (Ph. D., Cornell University, 1956, p. 62).

39 Palmer, Monte: Some Political Determinants of Economic Reform: Agrarian Reform in Iraq (Journal of Asian and African Studies, Vol. VI, No. 1, January 1971).

40 Op. cit., pp. 174-75.

41 Burki, Shahid Javed: Politics of Economic Decisionmaking During the Bhutto Period (Asian Survey, California, Vol. XIV, No. 12, Dec. 1974, pp. 1126-1140); Joshi, P. C.: Land Reform and Agrarian Change in India and Pakistan since 1947, Part I: pp. 164-185, Part II: pp. 326-362 (The Journal of Peasant Studies, London, Vol. 1, No. 2, January 1974, No. 3, April 1974). 
forces unleashed by Ayub could not be absorbed in the narrow period of turmoil that saw the strange phenomenon of Ayub attempting to mobilize the traditional elite to fight the groups he had himself emancipated" 42 .

The dominance of the political factors as compared to the socio-economic ones is characteristic for all countries in which the social classes are only marginally developed. A change of the political trend on account of changing coalitions, the importance of idiosyncratic factors, the undefinability and imprevisibility of government policy in general result from this unstable social situation ${ }^{43}$.

\subsection{The quest for legitimacy: The government in power challenged by internal or external threats}

However, land reforms can also be initiated by governments which have been in power for a rather long period if pressure is exerted on them. This pressure can have its origin within the society or in the international system. The attitude of government is generally determined by the way in which it assesses the costs if the demands are satisfied. If its legitimacy is contested by the rural lower strata, it can react to this by enforcing a land reform. If it does not consider this challenge to be very incriminatory, it contents itself with passing laws "on paper" or by making verbal proclamations without their being followed by actions.

The legitimacy of a government can, basically, be questioned under three aspects which could cause that government to enforce land reforms: The peasants' dissatisfaction expressed in spontaneous and organized acts, can cause the government to take action. The reform measures in the Philippines are largely explained by this fact. If their actual implementation was often limited, they were always implemented with priority in the districts where the dissatisfaction of the peasants was most important. In 1972 the Philippine President admonished his administration "to set up pilot projects in the most strategic areas, if possible in all the regions where tenancy has been generating social unrest" 44 .

The threat can also come from an opposition party which has formulated a programme of agrarian reform und thereby threatens to withdraw the rural base of the ruling party. Vollmer ${ }^{45}$ reports on a series of (fictitious) activities of the Congress Party in India which did not want to abandon the field to communists and to other left-wing parties as regards land reform.

The competitive claim to legitimation can come from the international system and cause the government to intensify its effort towards a reform: the early and consequent replacement of the zamindars in Cashmere (1949), which was (and is) claimed by Pakistan, the Latin American (fictitious) reforms of the sixties was answer to the challenge of the Cuban Revolution, the consequent land reform in Taiwan on account of the permanent threat of the victorious opponent of the civil war hitherto, have also to be understood under this aspect. In Taiwan, two other

42 Burki, Shahid, Javed: 1974, op. cit., p. 1132.

43 Autorenkollektiv: Klassen und Klassenkampf in den Entwicklungsländern, Bd. 3: Die Wahl des Weges, Berlin Ost 1969 (Bd. 1), Bd. 3 1970, p. 257).

44 Letter of Instructions No. 46, Dec. 7, 1972; quoted by: Hanisch, Rolf: Decision-making Processes and Problems of Implementation of the Land Reform in the Philippines (in: Asia Quarterly, forthcoming).

45 Vollmer, Franz-Josef: Die politische Problematik der Agrarfrage in Indien. Unter besonderer Berücksichtigung des Verhaltens der politischen Parteien (Heidelberg 1967 [Diss.], p. 31 u. p. 105). 
factors have contributed to the fact that in this country one of the most successful land reforms in a non-socialist country have an important part to play, has been enforced. It can be said that the political and the land-owning elites were members of various "nationalities". In such cases, it is possible for the land-owning class to maintain its position only under two conditions: it must practice a relatively efficient agriculture with a high output which, on its being dismissed, would threaten to collapse. Further, it would need strong external allies in the International System which would not tolerate implicitly and without sanctions its expropriation and dismissal. Both of these did not apply to Taiwan. The Taiwanese class of landowners lacked external allies in particular. Instead, the political pressure from the International System, from the Chinese mainland on the one hand, and from the USA on the other hand, had an effect on its being deprived of power.

The situation is different as regards the American plantations in Central America. As has been shown in Guatemala, these could mobilize the still dominant power in that region, the USA, to protect their interests ${ }^{46}$. The fate of the land-owning Hindus who were expelled from their possessions in East Pakistan at the time was different. They had indeed an external relation to India but could not obtain sufficient support from her ${ }^{47}$

Kenya's example is also informative in that connection. The pressure from the basis, which expressed itself in the Mau-Mau riots ${ }^{48}$ caused the colonial government to extend its activities in agricultural development to African agriculture (as "compensatory measure" ${ }^{49}$ ). Later, it became aware that a land transfer of the European farms to the Africans and political independence would be unavoidable. Against the oppostion of the white settlers, it enforced both; against the African nationalists, the beginning and the conditions of land reform. It secured that European farmers receive for the land an almost full compensation, half of which, moreover, was to be paid to them immediately, and the rest in three annual instalments. At the same time, it hoped - and this was in accordance with the interest of the African political elite around Kenyatta - to keep production losses at a minimum. Together with the credits granted by other international donors (World Bank, Federal Republic of Germany), $86 \%$ of the indeed considerable costs of the agrarian reform, more than 25 Mill. £ (1961-1968), were (pre-) financed by international donors. $47 \%$ thereof were utilized for the purchase of land alone, $22 \%$ for administration etc. and $23 \%$ only for development measures ${ }^{50}$. Although the peasants had to pay only $2 / 3$ of the purchase price, they had considerable difficulties to refund the credits granted to them to that end. As they could still be evicted from the land as long as they had not effected full payment, their security had hardly been increased. Their dependence had only shifted from the European settlers to the African bureaucracy. In the meantime, the political elite succeeded in acquiring the best land and the largest

46 The Arbenz-government tried to distribute the uncultivated surplus-land of the United Fruit Company, but was toppled by an CIA-inspired and supported invasion army (under Castillo Armas), 1954, cf.: Melville, Thomas: Guatemala - Another Vietnam? (Harmondsworth 1970, p. 310).

47 Bredo, William: Land Reform and Development in Pakistan (in: Froehlich, Walter [ed.]: Land Tenure Industrialization and Social Stability: Experience and Prospects in Asia, Milwaukee, Wisc. 1961, p. 263).

48 Cf. Barnett, Donald: Mau Mau from within (London 1966); Buytenhuys, Robert: Le Mouvement “MauMau": une révolte paysanne et anticoloniale en. Afrique noire (The Hague 1971); Rosberg, C. G.; Nottingham, J.: The Myth of "Mau Mau" Nationalism in Kenya (New York 1966).

49 Harbeson, John W.: Nation Building in Kenya. The Role of Land Reform (Evanston 1973).

50 Herz, Barbara K.: Land Reform in Kenya (AID Spring Review of Land Reform June 1970, Second Edition, Vol. IX). 
allotments (100 acres instead of the usual 27-37) with the (European) mansions. As their European predecessors they let wage-earners cultivate these lands. Althouth the land transfer from Europeans to Africans has, by far, not yet been completed, the government, since the end of the sixties, made it clear to the "efficient" European farmers that it was interested in their remaining in the country (and in their high market production). Once more, "growth" (of production) had won through over "equity". 


\title{
Agrarian Reforms and the Societal and Political Interests of Townspeople in LDCs
}

\author{
By Rolf Hanisch
}

In many LDCs - namely in Asia and Latin America - agrarian reforms are considered as one of the necessary prerequisites for an overall social development in which the lower classes also participate. However, relatively few countries have carried out effective agrarian reforms. This cannot be explained solely by the dominating political influence of the landlords, which, more of ten than not, is no longer existant. Here, it is much more the attitude of the urban strata which plays a decisive role. But, in general, their interest focused primarily on the infrastructural and industrial development of the urban area, the rural one being neglected. The aggravation of the agrarian crisis, which now also took universal dimensions, first obliged the (urban dominated) governments to intensify their development efforts in the rural area as well. These efforts, however, were extended mostly to technocratic measures of production development.

The announcement and (often only inconsequent) implementation of agrarian reforms can be mostly explained out of three situations in the political process, when the (primarily urban) elites try to extend their (rural) legitimation basis. Thereby, it can be a question of opposition groups which try to expand their legitimacy by taking up the question of agrarian reforms as their theme. By gaining power, they can try to legitimate their authority by effecting reforms and/ or who also try to withdraw the economic basis of the hitherto ruling elites. Finally, agrarian reforms can also be effected by governments which have been in power for long, if pressure is put on them. This can originate from an opposition group, a peasants' movement or from actors from the international system.

\section{Rural Land Reform in Socialist Ethiopia: The First Year}

\author{
By Harrison C. Dunning
}

In this review of the first year of rural land reform in socialist Ethiopia, the author deals with two major legislative reforms. Initially the government which overthrew Haile Sellassie adopted a Rural Lands Proclamation, which was based upon the classical notion of "land to the tiller". Cultivators were confirmed in nontransferable "possessory rights" over the land under cultivation, and provision was made for redistribution of land by peasant associations in order to give cultivators parcels approximately equal in size. These reforms were more successful in southern than in northern Ethiopia, for it was the south which had known widespread agricultural tenancy with heavy burdens placed upon the tenant. Even in the south, however, little redistribution of land from peasant to peasant took place. In a second reform, the Peasant Associations Proclamation, redistribution of land is replaced as the major goal by the development of a socialist agriculture in which the peasant association is of critical importance. The author concludes that at the end of Ethiopia's first year of rural land reform, the future was very 